\title{
Effects of dietary Aloe vera and Echinacea on some nonspecific immu- nity in shirbot (Barbus grypus)
}

\author{
M Mesbah, T Mohammadian, M Alishahi and A Jangaran Nejad \\ Department of Clinical Sciences, Faculty of Veterinary Medicine, Shahid Chamran University, Ahvaz, Iran
}

Recived: July 2015

\begin{abstract}
A feeding trial was conducted for sixty continuous days to determine the effect of dietary Aloe vera and Echinacea on immunological parameters of shirbot (Barbus grypus). Four hundred and twenty fish weighing 50-60 $\mathrm{g}$ were randomly subjected to seven different treatment, including one control (Aloe vera and Echinacea free diet), A1 ( $0.1 \%$ of Aloe vera), A2 $(0.2 \%$ of Aloe vera), A3 $(0.5 \%$ of Aloe vera), E1 ( $0.1 \%$ of Echinacea), E2 (0.2\% of Echinacea), E3 (0.5\% of Echinacea) each in triplicate. Some immunological parameters such as respiratory burst activity, Complement activity, Lysozyme activity, serum bactericidal activity, total protein and albumin were assessed. At the end of treatment, 30 fish from each group were challenged with Aeromonas hydrophila. No significant difference was seen in respiratory burst activity of Aloe vera and Echinacea treatments compared to the control group $(\mathrm{P}>0.05)$. Complement and serum bactericidal activity enhanced in all the Aloe vera groups $(\mathrm{P}<0.05)$. Total protein and globulin in Aloe vera and Echinacea treatments decreased compared with control group $(\mathrm{P}>0.05)$. Lysozyme activity in $0.2 \%$ Aloe vera treatments was significantly higher than Echinace and control groups $(\mathrm{P}<0.05)$. According to obtained results, it might be concluded that the feeding of this species by Aloe vera (specifically $0.2 \%$ ) extract could likely enhance immunological parameters better than Echinacea.
\end{abstract}

Correspondence T Mohammadian, Department of Clinical Sciences, Faculty of Veterinary Medicine, Shahid Chamran University, Ahvaz, Iran (e-mail: T.mohammadian@scu.ac.ir)
Accepted: December 2015

Keywords: Aloe vera, Barbus grypus, Echinacea, immunological parameters.

\section{Introduction}

Aquaculture is the fastest growing food-producing component in the world. Intensification of aquaculture has led to high number of disease outbreaks with an increasing range of pathogens causing them (Kirubakan, Alexander \& Dinakaran 2010). Seemingly, vaccination is the most promising method of controlling fish disease which enhances the specific immune response of fish (Press \& Lillehaug 1995; Ardo, Yin, Xu, Varadi, Szigeti, Jeney \& Jeney 2008). However, effective vaccines for a number of pathogens like the bacterium Aeromonas hydrophila have not been developed due to their heterogeneity. Furthermore, a single vaccine is effective against only one type of pathogens (Leong \& Fryer 1993; Murray, Pascho, Alcorn, Fairgrieve, Shearer \& Roley 2003; Gopalakannan \& Arul 2006; Ardo et al. 2008) and vaccination of very young fish is also difficult (Kaattari \& Piganelli 1997; Murray et al. 2003) Moreover, infectious bacterial, parasitic and fungal diseases are mainly controlled by chemotherapeutics and antibiotics. However, recently the use of antibiotics and chemotherapy has been criticized because their use has created problems with drug resistance bacteria, toxicity, the imbalance of the normal beneficial intestinal flora and accumulation both in fish and environment (Farag, Daws, Hewedi \& El-Barotyl 1989; Citarasu, Babu, Sekar \& Marian 2002; Sağdiç \& Özcan 2003).

Immunostimulants seem to represent a useful alternative to vaccination and chemotherapy in the control of fish diseases. Immunostimulants are natural or synthetic substances that are able to activate non-specific and specific immune responses (An- 
derson 1992; Siwicki, Anderson \& Rumsey 1994; Verlhac, Obach, Gabaudan, Scheup \& Hole 1998; Sakai 1999; Esteban, Mulero, Cuesta, Ortuno \& Meseguer 2000). Immunostimulants mainly facilitate the function of phagocytic cells and increase their bactericidal activities. Several immunostimulants also stimulate lysozyme activity and the antibody responses of fish (Sakai 1999). They attach to specific receptors on the cell surface of the phagocytes and lymphocytes activating these cells to produce enzymes capable of destroying pathogens. In addition, they can increase the production of chemical messengers (interferon, interleukins and complement proteins) that stimulate other aspects of the immune system and increase the activity of $\mathrm{T}$ and $\mathrm{B}$ lymphocytes (Raa 1996). The use of immunostimulants for the prevention of fish diseases progresses and several preparations and regimes has become more promising (Jeney \& Jeney 2002). To date, it has been proved that administration of herbs can improved the innate and adaptive immune response of different freshwater or marine fish and shellfish against bacterial, viral, and parasitic diseases (Harikrishnan, Balasundaram \& Heo 2011).

Aloe vera is a perennial plant of Liliaceae or Aloeaceae family, which is a tropical or subtropical plant (Lawless \& Allan 2000). Acemannan is considered to be the main functional component of Aloe vera and is composed of a long chain of acetylated mannose (Lee, Lee, Yun, Kim, Kim \& Kim 2001). Fragments of Aloe vera activate macrophages, stimulate the immune system and have antibacterial and antiviral effects (Choi, Son, Son, Park, Lee \& Chung 2001; Pugh, Ross, El Sohly \& Pasco 2001; Tan \& Vanitha 2004). Beneficial effects of Aloe vera in human and laboratory animals are contributed to the promotion of immune system, anti-inflammatory, pro-healing, gastrointestinal, antidiabetic and anti-arthritic effects (Pugh et al. 2001).

Echinacea is a plant genus, belonging to the Asteraceae family, comprised of 9 species, only 3 being used as medicinal plants (E. angustifolia, E.pallidaand E. purpurea). Echinacea has immunostimulating effects (for the non-specific immune system), anti-inflammatory and anti-tumor effects. The effects of Echinacea on Nile tilapia (Oreochromis niloticus) were studied and results showed better growth parameters and a better resistance against Pseudomonas fluorescens (Gabor, Aurel, Bentea, Calina \& Anca 2012). Echinacea seems to activate the macrophages and other immunological functions in lab animals and humans and there is considerable evidence of the role played by the polysaccharide fraction in the immunostimulatory effect of Echinacea preparations. The polysaccharides (heteroglycans), isolated from E. purpurea, have been particularly investigated in their capacity to activate macrophages and other components of the immune system in mice, rats and humans (Bauer 1999).

In fish therapy efforts reported from many parts of the world, chemical drugs in aquaculture industry have been replaced by herbal medicine (Dügenci, Arda \& Canadan 2003; Citarasu, Sivaram, Immanuel, Rout \& Murugan 2006). The role of plant extracts in stimulating the fish immune system challenged with bacterial, parasitic, and fungal agents has been the subject of many studies (Sivaram, Babu, Immanuel, Murugadass, Citarasu \& Marian 2004; Vasudeva \& Chakrabarti 2005; Citarasu et al. 2006; Vasudeva, Das, Jyotyrmayee \& Chakrabarti 2006; Divyagnaneswari, Christybapita \& Dinakaran 2007).

There is limited information available on the immunostimulatory, anti-toxicity and growth effects of Aloe vera and Echinacea in some fish species (Kim, Hwang \& Bai 1999; Alishahi, Ranjbar, Ghorbanpour, Peyghan, Mesbah \& Razi jalali 2010; Zodape 2010; Wang, Xu, Xu, Zhu, Zheng \& Sun 2011).

This study was undertaken to evaluate the effects of Aloe vera and Echinacea extracts on the immunity responses in shirbot (Barbus grypus) to develop an alternative drug to chemotherapeutics in aquaculture.

\section{Materials and Methods}

\section{Fish and water sources}

Four hundred and twenty juveniles of shirbot with average body weight $50 \pm 5 \mathrm{~g}$, were obtained from a fish farm in Dezful, Khuzestan province, Southwest Iran. Fish were transferred to our laboratory 
and were kept in plastic tank. All fish were then adapted within one week prior to experiment. Water quality parameters, including temperature $25^{\circ} \mathrm{C}$, dissolved oxygen 8-10 mg L-1, pH 7.9, NO2 <0.01 mg L- 1 and NH3 $<0.1 \mathrm{mg} \mathrm{L}-1$ were recorded daily during the experiment. The only $10 \%$ of total water were exchange daily to reduce the risk of metabolic toxicosis.

\section{Diets preparation}

The experimental diets were prepared by mixing of normal shirbot food with crude extract of Aloe vera and Echinacea. For better homogenization, one volume of the crude extract of Aloe vera and Echinacea were dissolved in 5 volume water and then the homogenized solutions were sprayed at the rate of $0.1,0.2$ and $0.5 \%$ onto a thin layer of food. The Aloe vera and Echinacea free diets were sprayed by the same method with only water.

\section{Fish Grouping and Treatments}

As mentioned earlier, following the acclimation period, for each of Aloe vera and Echinacea treatments, 240 fish were selected and were randomly distributed into twelve tanks, three replicates for each treatment (i.e. 20 fish were maintained in each 100 L tank), which equipped with thermostatic heater, aeration and external biofilters. Then 8 groups named a follows:

All treatments were fed twice daily at 5\% body weight during the experimental period (for 2 months).

\section{Sampling}

At the end of experiment, after they were anesthetized with eugenol $(1: 10,000)$ (Shanghai Reagent, China), for serum separation, blood samples were obtained from the caudal vein of randomly chosen 5 fish from each tank by using syringe and transferred to microtube without heparin and allowed to clot for $1 \mathrm{~h}$ at room temperature and then $2 \mathrm{~h}$ at $4{ }^{\circ} \mathrm{C}$. Serum was isolated from the remaining blood after centrifugation $(3000 \times \mathrm{g}$ for $10 \mathrm{~min})$. Also $0.5 \mathrm{~mL}$ blood transferred into microtube containing heparin and shaken gently for NBT measurement.

\section{Nitro blue tetrazolium assay (NBT)}

The respiratory burst activity was measured by the reduction of nitro blue tetrazolium (NBT) by intracellular superoxide radicals (Anderson \& Siwicki 1994). Briefly, $100 \mathrm{~mL}$ of heparinised blood from fish of each group was mixed with $100 \mathrm{~mL}$ of $0.2 \%$ NBT (Sigma, USA) solution for $30 \mathrm{~min}$ at $25{ }^{\circ} \mathrm{C}$. After incubation, $50 \mathrm{~mL}$ from the above mixture was added with $1 \mathrm{~mL}$ of $\mathrm{N}, \mathrm{N}$ diethylmethyl formamide (Qualigens, India) and then centrifuged at $3000 \mathrm{~g}$ for $5 \mathrm{~min}$. The optical density of the supernatant was measured at $540 \mathrm{~nm}$.

\section{Complement activity}

The complement activity was assayed using Rabbit red blood cells (RaRBC) as target. RaRBC was provided in $1.5 \%$ agarose ( $\mathrm{PH}$ 7.2), containing 0.5 $\mathrm{mM} \mathrm{MgCl} 2$ and $1.5 \mathrm{mM} \mathrm{CaCl} 2 . \mathrm{RaRBC}$ in agarose were washed with PBS ( $0.1 \mathrm{M} \mathrm{pH}=7.0)$ by centrifugation at $750 \mathrm{~g}$ for $5 \mathrm{~min}$ and the cell concentration adjusted to $1 \times 108$ cell $\mathrm{mL}-1$. Agarose containing RaRBC was dispensed into plate, incubated at 4 ${ }^{\circ} \mathrm{C}$ and punched ( $3 \mathrm{~mm}$ in diameter). Subsequently each hole was filled with 15 microliter of serum of shirbot and incubated at room temperature. After 24 $\mathrm{h}$ of incubation, the zone of lysis was measured and expressed in AU mL-1. (Navinchandran, Lyapparaj, Moovendhan, Ramasubburayan, Prakash, Immanuel \& Palavesam 2014).

Arbitrary Unit $(\mathrm{AU} \mathrm{mL}-1)=($ Zone of lysis $/$ Volume of the sample loaded) $\times 1000$

\section{Lysozyme activity assay}

Serum lysozyme activity was measured as described by Ellis (1990). Briefly, $10 \mu$ of serum was mixed with $200 \mu \mathrm{l}$ of a Micrococcus lisodeichticus (Sigma) suspension at $0.2 \mathrm{mg} \mathrm{mL}$ in $0.05 \mathrm{M}$ sodium phosphate buffer ( $\mathrm{pH}$ 6.2). The mixture was incubated at $27^{\circ} \mathrm{C}$, and its OD was detected after 1 and $6 \mathrm{~min}$ at $530 \mathrm{~nm}$ using an ELISA (enzyme-linked immunosorbent assay) plate reader. One unit of lysozyme activity was defined as the amount of enzyme that produced a decrease in absorbance of $0.001 \mathrm{~min} \mathrm{~mL}-1$ serum. Lysozyme concentrations 
were calculated using a standard curve of lysozyme from chicken egg white (Sigma) concentrations.

\section{Serum bactericidal activity}

The method used for serum bactericidal activity was followed a modified version of that adopted by some researchers (Kajita, Sakai, Atsuta \& Kobayash 1990). The serum samples were diluted three times with $0.1 \%$ gelatin-veronal buffer $(\mathrm{GVB}+2 ; \mathrm{pH} 7.5$, containing $0.5 \mathrm{mM} \mathrm{ml} \mathrm{Mg}$ and $0.15 \mathrm{mM} \mathrm{ml} \mathrm{Ca+2)}$. A. hydrophila (live washed cells) were suspended in the same buffer to make a concentration of $1 \times 10 \mathrm{cfu}$ $\mathrm{mL}-1$. The diluted sera and bacteria were mixed at a ratio of $1: 1$ and incubated for $90 \mathrm{~min}$ at $25^{\circ} \mathrm{C}$ and continuously agitated. The number of viable bacteria was then calculated by counting the resultant colonies from the incubated mixture on TSA (tryptic soy agar) plates after incubation for $24 \mathrm{~h}$ in duplicate.

\section{Total serum protein and globulin}

Samples were analyzed for total protein using the method outlined by Lowry, Rosebrough, Farr \& Randall (1951). Albumin content was measured using a standard albumin estimation kit (Zistchem Diagnostics, Iran) and the globulin content was estimated by subtracting albumin from total protein.

\section{Challenge test}

A. hydrophila AH04 was grown in nutrient broth and incubated at $37{ }^{\circ} \mathrm{C}$ for $24 \mathrm{~h}$. Lethal dose 50 (LD50) of A. hydrophila (that killed 50\% of the test large B. grypus) was determined by intraperitoneal injection of 60 fish with different doses A.hydrophila $\left(106,107,108\right.$ and $109 \mathrm{CFU}$ fish-1) at $25^{\circ} \mathrm{C}$ and the probit analysis of mortality rates showed that the LD50 on day 10 was $3.7 \times 108$ CFU fish- 1 . At the end of experiment (Sixteen days after experimental feeding), a challenge infection with A. hydrophila was carried out to test immune-stimulating effects of Aloe vera and Echinacea. The challenge group was intraperitoneally injected with $0.2 \mathrm{~mL}$ PBS containing $3.7 \times 108 \mathrm{CFU} \mathrm{mL}-1$ live A. hydrophila, while the Control fish received $0.2 \mathrm{~mL}$ PBS. The cumulative mortality was calculated 10 days after challenge.

\section{Statistical analysis}

SPSS version 19 software was used for statistical analysis of data. Analysis of Variance (ANO$\mathrm{VA}$ ) was used for comparison of means among all groups and the student's t-test was used for comparison of data between the groups treated with Aloe vera, Echinacea and the Control groups. A p-value of $<0.05$ was accepted as significant.

\section{Results}

\section{Respiratory burst activity}

At 60 days after feeding, respiratory burst activity enhanced in fish treated with $0.2 \%$ (A2) and $0.5 \%$ (A3) of Aloe vera and $0.5 \%$ (E3) Echinacea extracts supplementation feed as compared to control group (Fig. 1). However, the increase in levels were not significant $(\mathrm{P}>0.05)$.

\section{Complement activity}

The complement activity significantly $(\mathrm{P}<0.05)$ increased in all Aloe vera treated groups corresponding to the feeding duration. The rate of increase was the highest in the A2 Aloe vera group followed by the A1 and A3 Aloe vera fed group (Fig. 2). There were distinct differences among the Aloe vera group than Echinacea in the complement activity.

\section{Lysozyme activity}

The serum lysozyme activity increased in $0.2 \%$ (A2) Aloe vera treated group (Fig. 3). A2 group was higher than others $(129.5 \pm 16.9)$ in this experiment and only this treatment differences in the lysozyme activity with the control group was significant $(\mathrm{P}<0.05)$.

\section{Serum bactericidal activity}

After Aloe vera feeding, the ability to kill A. hydrophila was more powerful in fish serum, specific A3 and A2 groups, respectively than in the control fish serum, but all Echinacae, they had marginally increase in their bactericidal activity (Fig. 4).

\section{Total protein and globulin}

Total protein levels insignificantly in the fish fed 
Table 1 The experimental design applied in this study.

\begin{tabular}{llll}
\hline Groups/Concentration & $0.1 \%$ & $0.2 \%$ & $0.3 \%$ \\
\hline Control & - & - & - \\
Aloe vera & A1 & A2 & A3 \\
Echinacea & E1 & E2 & E3 \\
\hline
\end{tabular}

Table 2 Total Protein and Globulin in B. grypus that were feeding Diet containing A1 (0.1\% Aloe vera), A2 (0.2\% Aloe vera), A3 (0.5\% Aloe vera), E1 (0.1\% Echinacea), E2 (0.2\% Echinacea), E3 (0.5\% Echinacea) and Control group only with basic diet. Data in the column with asterisk, significantly differ $(\mathrm{P}<0.05)$ with the control group.

\begin{tabular}{lll}
\hline Treatment & Total Protein & Globulin \\
\hline A1 & $4.34 \pm 2$ & $2.37 \pm 1.65$ \\
A2 & $4.06 \pm 1.61$ & $2.20 \pm 0.89$ \\
A3 & $4.69 \pm 1.37$ & $2.07 \pm 1.34$ \\
Control & $4.33 \pm 1.19$ & $2.106 \pm 1.11$ \\
E1 & $4.10 \pm 2.35$ & $2.62 \pm 1.52$ \\
E2 & $4.49 \pm 1.6$ & $2.65 \pm 0.56$ \\
E3 & $4.01 \pm 0.95$ & $2.49 \pm 0.93$ \\
\hline
\end{tabular}

Table 3 Rate of mortality in B. grypus that were challenged to Diet containing A1 (0.1\% Aloe vera), A2 ( $0.2 \%$ Aloe vera), A3 ( $0.5 \%$ Aloe vera), E1 (0.1\% Echinacea), E2 ( $0.2 \%$ Echinacea), E3 (0.5\% Echinacea) and Control group only with basic diet. Data in the column with asterisk, significantly differ $(\mathrm{P}<0.05)$ with the control group.

\begin{tabular}{llll}
\hline Treatment & No. of fish & No. of mortality & $\begin{array}{l}\text { Mortality rate } \\
(\%)\end{array}$ \\
\hline A1 & 30 & 13 & $43.3^{*}$ \\
A2 & 30 & 9 & $30.0^{*}$ \\
A3 & 30 & 16 & 53.3 \\
control & 30 & 19 & 63.3 \\
E1 & 30 & 14 & $46.6^{*}$ \\
E2 & 30 & 17 & 56.6 \\
E3 & 30 & 17 & 56.6 \\
\hline
\end{tabular}

enriched by Aloe vera and Echinacea in this experiment when compared with control group. There was observed similar trend in the globulin levels in plasma of fish fed by food enriched with Aloe vera and Echinacea during experimental period (Table 1).

\section{Challenge test}

There were significant differences in the cumulative mortality rate among some herbal extract treated and control groups. The first mortality of fish in the A. hydrophilla challenge trial began at $17 \mathrm{~h}$ post infection (HPI) in all the test groups. The cause of death of all the dead fish observed in the challenge trials was A. hydrophilla, as determined by bacterial isolation from spleen and kidney. Survival rates of A2 (70.0\%), A1 (57.7\%) and E1 (54.4\%) containing diets were significantly higher than that of fish fed the control diet (41.0\%). Mortality occurred continuously until 72 HPI (Table 2).

\section{Discussion}

The present study investigated the immunostimulatory properties of Aloe vera and Echinacea on immunological parameters of shirbot. Results showed that respiratory burst activity increased in 0.2 and $05 \%$ Aloe vera and also $0.5 \%$ Echinacea treatments. Complement activity and serum bactericidal activity enhanced in all the Aloe vera groups compared with control group. Total protein and globulin in Aloe vera and Echinacea groups decreased compared with control group. Lysozyme activity in 0.1 and $0.2 \%$ Aloe vera treatments increased.

However, world aquaculture production is vulnerable and an increase of disease outbreaks has been reported due to culture intensification, resulting in partial or total loss of production (Bondad-Reantaso, Subasinghe, Arthur, Ogawa, Chinabut, Adlard, Tan \& Shariff 2005). Factors such as overcrowding, periodic handling, high or sudden changes in temperature, poor water quality and poor nutritional status contribute to physiological changes in fish such as stress or immunosuppression and thus, heighten susceptibility to infection. Moreover, high concentrations of fish and lack of sanitary barriers facilitate the spread of pathogens, producing high mortality levels (Naylor, Goldburg, Primavera, Kautsky, Beveridge, Clay, Folke, Lubchenco, Mooney \& Troell 2000; Cabello 2006; Quesada, Paschoal \& Reyes 2013).

The immune system is classified into innate (non-specific) and adaptive (specific) immune systems. The innate immune system is the first line of defense against invading pathogens and their major components are macrophages, monocytes, granulocytes, and humoral elements, including lysozymes or complement systems (Harikrishnan, Balasundaram, Kim, Kim, Han \& Heo 2009). An immuno- 


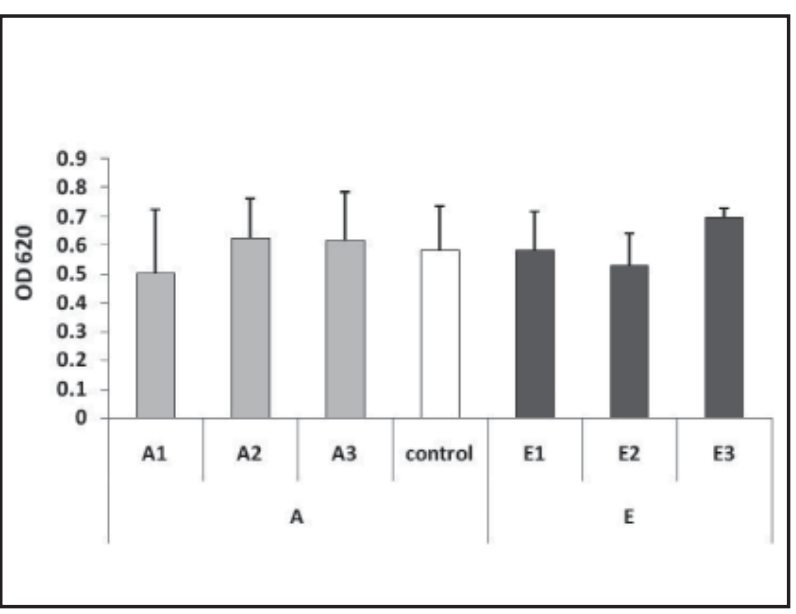

Figure 1 Reduction of NBT in blood collected from juvenile shirbot. Diet containing A1 (0.1\%Aloevera), A2 (0.2\%Aloe vera), A3 (0.5\%Aloe vera), E1 $(0.1 \%$ Echinacea $)$, E2 $(0.2 \%$ Echinacea $)$, E3 $(0.5 \%$ Echinacea $)$ and Control group only with basic diet. Data represent means \pm SD of a triplicate set of nine fish. Statistical significance differences $(\mathrm{P}<0.05)$ between each treatment and control group are represented by asterisk.

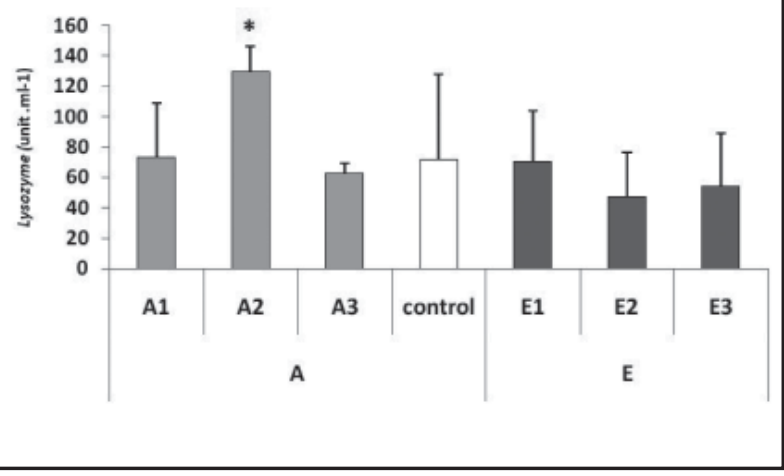

Figure 3 Lysozyme activity of blood collected from juvenile shirbot. Diet containing A1 (0.1\%Aloe vera), A2 (0.2\%Aloe vera), A3 (0.5\%Aloe vera), E1 (0.1\%Echinacea), E2 $(0.2 \%$ Echinacea), E3 (0.5\%Echinacea) and Control group only with basic diet. Data represent means \pm SD of a triplicate set of nine fish. Statistical significance differences $(\mathrm{P}<0.05)$ between each treatment and control group are represented by asterisk.

stimulant is a substance that enhances the defense mechanisms or immune response (both specific and non-specific), thus rendering the animal more resistant to diseases and external aggressions (Anderson 1992). An increasing interest in the use of plant extracts as fish immunostimulants has arisen in the last decade (Galina, Yin, Ardo \& Jeney 2009; Vaseeharan \& Thaya 2013). Several studies have monitored the immunological parameters after in-

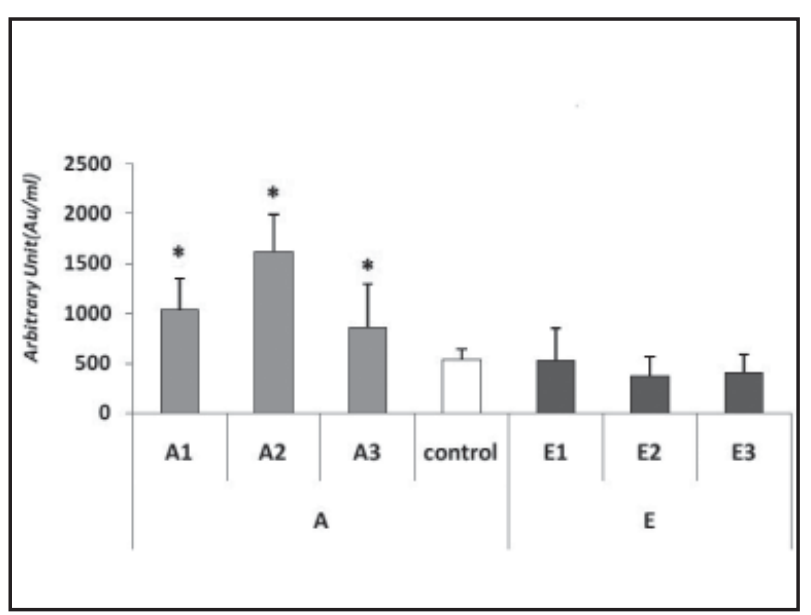

Figure 2 Complement activity of blood collected from juvenile shirbot. Diet containing A1 (0.1\%Aloe vera), A2 (0.2\%Aloe vera), A3 (0.5\%Aloe vera), E1 (0.1\%Echinacea), E2 $(0.2 \%$ Echinacea $)$, E3 ( $0.5 \%$ Echinacea $)$ and Control group only with basic diet. Data represent means \pm SD of a triplicate set of nine fish. Statistical significance differences $(\mathrm{P}<0.05)$ between each treatment and control group are represented by asterisk.

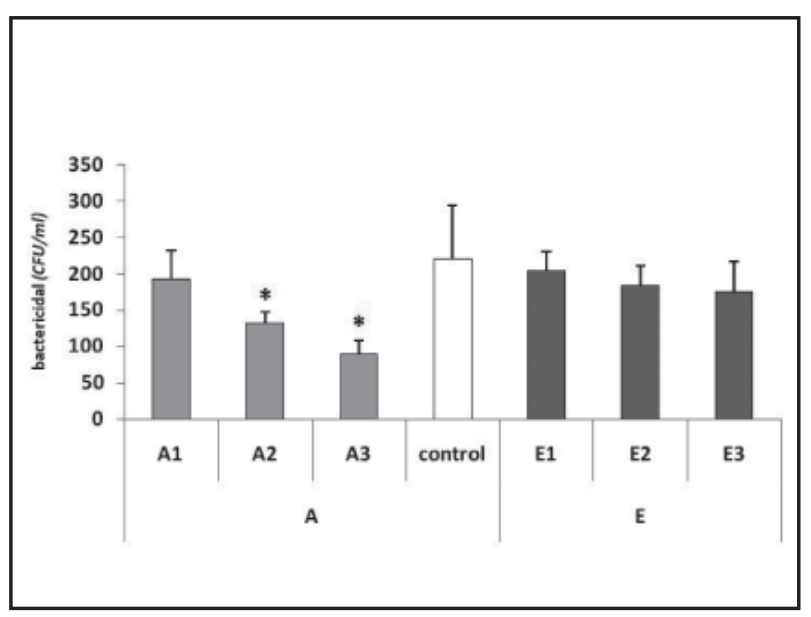

Figure 4 bactericidal activity of blood collected from juvenile shirbot. Diet containing A1 (0.1\%Aloe vera), A2 (0.2\%Aloe vera $),$ A3 (0.5\%Aloe vera), E1 $(0.1 \%$ Echinacea $)$, E2 $(0.2 \%$ Echinacea $)$, E3 $(0.5 \%$ Echinacea $)$ and Control group only with basic diet. Data represent means \pm SD of a triplicate set of nine fish. Statistical significance differences $(\mathrm{P}<0.05)$ between each treatment and control group are represented by asterisk.

traperitoneal injection or orally administered plant extracts on distinct fish species and they found that treated fish showed increased lysozyme activity, phagocytic activity, complement activity, increased respiratory burst activity and increased plasma protein (globulin and albumin) (Dügenci et al. 2003; Yuan, Li, Chen, Sun, Wu, Gong, Tang, Shen \& Han 2007; Wu, Liu, Chang \& Hsieh 2010).

Recent studies have shown that herbal supple- 
ments to feed increased disease resistance in fish and improved survival and growth in rats, which may be attributed to improvement of immune functions (Christybapita, Divyagnaneswari \& Dinakaran 2007; Divyagnaneswari et al. 2007; Ardo et al. 2008; Cheng, Chen \& Chen 2008). Also within aquaculture, there are many studies reporting herbal medicine extracts can be used as immunostimulants to enhance non-specific immune system of cultured fish species (Sakai 1999; Shao, Xu, Dai, Tu, Li \& Gao 2004; Tan \& Vanitha, 2004; Rao, Das, Jyotymayee \& Chakraborli 2006; Sahu, Das, Pradhan, Mohopatra, Mishra \& Sarangi 2007).

Respiratory burst activity considered as an important indicator of non-specific defense in fish, which is a measure of the increase oxidation level in phagocytes stimulated by foreign agents (Liaghat, Akhlaghi, Hosseini, Nematollahi \& Hosseini 2011). Respiratory burst is also a crucial effector mechanism for limiting the growth of fish pathogens (Divyagnaneswari et al. 2007). Respiratory burst and phagocytosis response by phagocytes in blood considered to have a major antibacterial defense mechanism in fish (Harikrishnan, Balasundaram \& Heo 2010). The results obtained in present study showed an increasing trend in respiratory burst activity in treated groups in comparison with control group. Results of this research are in agreement with results of some studies which dietary immunostimulants used in various fish species (Yin, Ardo, Thompson, Adams, Jeney \& Jeney 2009; Bilen \& Bulut 2010). Also, this is consistent with result found in rainbow trout (Haghighi \& Sharifrohani, 2013).

In the present study, dietary supplemented by Aloe vera extract enhanced complement and lysozyme activity in comparison with Echinacae and control group. Lysozymal activity is an important defense mechanism in fish, which causes lysis of bacteria and activation of the complement system and phagocytes by acting as an opsonin (Harikrishnan, Kim, Hong, Mariappan, Balasundaram \& Heo 2012). Elevated lysozyme level was measured in crucian carp (Chen, Wu \& Yin 2003), large yellow croaker (Jian \& Wu 2003) and the common carp (Jian \& Wu 2004) after the fish were fed with vari- ous herbal extracts that included Eclipta alba, Radix astragalinseu, Hedysari and Radix angelicaesinensis. An increasing lysozyme activity in this research concomitant with several indicating the role of herbal immunostimulants in enhancing lysozyme activity (Vasudeva et al. 2006; Choi, Park, Yoon, Kim, Jang \& Choe 2008) and is consistent with the results in common carp (Alishahi et al. 2010), But results of Echinacea treatments is in coherence with the result found in Nile tilapia (Aly, Mohammed \& John 2008). Complement includes over 20 different plasma proteins that are produced by a variety of cells including, hepatocytes, macrophages, and gut epithelial cells. Some complement proteins bind to immunoglobulins or to membrane components of cells. The complement system is an essential and effective part of the innate immune system. It can rapidly distinguish and opsonize bacteria for phagocytosis by specialized phagocytes or destroy them directly by membrane disorder (Rooijakkers \& van Strijp 2007). Thus, the increase of the complement activity in plasma of fish may help to identify and eliminate bacteria agents by phagocytosis. According to results of this study, complement activity of fish fed the feed enriched with Aloe vera (Specific $0.2 \%$ ) was increased that may indicate an improvement of the capabilities of the fish immune system during the experimental period. This result is in agreement with results of several studies that showed an increase in complement activity following administration of different immunostimulants such as herbal derivatives (Jian \& Wu 2003; Jian \& Wu 2004; Christybapita et al. 2007), sodium alginate (Bagni, Romano, Finoia, Abelli, Scapigliati, Tiscar, Sarti \& Marino 2005; Cheng et al. 2008), and vitamins $\mathrm{C}$ and $\mathrm{E}$ (Ortuño, Esteban \& Meseguer 1999; Ortuño, Cuesta, Esteban \& Meseguer 2001). Alishahi et al. (2010) reported that after Aloe vera administration in common carp, no significant difference was seen in the complement activity between Aloe vera treated and Aloe vera-free treatment.

In this study in carp, total serum protein and globulin content were decreased after oral administration of compared to controls. Certain herbal immunostim- 
ulants have been reported to increase total protein as well as total globulin in fish (Vasudeva, Romesh, Singh \& Chakrabarti 2004). However, other reports indicate a lack of immunostimulant influence on serum proteins in such populations (Ispir \& Dörücü 2005; Misra, Das, Mukherjee \& Meher 2006).

In conclusion, the present results have demonstrated that the oral administration of Aloe vera (specifically $0.2 \%$ ) in shirbot compared with Echinacea can enhance some of the non-specific immune responses. Therefore, we suggest that $0.2 \%$ extract addition is economically better than other concentrations. However, also, concentration $0.5 \%$ has good response in some parameters, but lower concentration is better as an economical viewpoints and biosecurity.

\section{References}

Alishahi M., Ranjbar M.M., Ghorbanpour M., Peyghan R., Mesbah M. \& Razi jalali M. (2010) Effects of dietary Aloe vera; on some specific and nonspecific immunity in the common carp (Cyprinus carpio). International Journal of Veterinary Research 4, 189-195.

Aly S.M., Mohammed M.F. \& John G. (2008) Echinacea as immunostimulatory agent in Nile tilapia (Oreochromis niloticus) via earthen pond experiment. In: Proceeding of the 8th International symposium on tilapia in aquaculture, pp. 1033-1042, Cairo.

Anderson D.P. (1992) Immunostimulants, adjuvants, and vaccine carriers in fish: applications to aquaculture. $A n$ nual Review of Fish Diseases 2, 281-307.

Anderson D.P. \& Siwicki A.K. (1994) Duration of protection against Aeromonas salmonicida in brook trout immunostimulated with glucan or chitosan by injection and immersion. The Progressive Fish Culturist 56, 258-261.

Ardo L., Yin G., Xu P., Varadi L., Szigeti G., Jeney Z. \& Jeney G. (2008) Chinese herbs (Astragalus membranaceus and Lonicera japonica) and boron enhance the non-specific immune response of Nile tilapia (Oreochromis niloticus) and resistance against Aeromonas hydrophila. Aquaculture 275, 26-33.
Bagni M., Romano N., Finoia M.G., Abelli L., Scapigliati G., Tiscar P.G., Sarti M. \& Marino G. (2005) Short and long term effects of a dietary yeast-glucan (Macrogard) and alginic acid (Ergosan) preparation on immune response in sea bass (Dicentrarchus labrax). Fish and Shellfish Immunology 18(4), 311-325.

Bauer R. (1999) Chemistry, analysis and immunological investigations of Echinacea phytopharmaceuticals. In: Immunomodulatory agents from plants (ed. by H. Wagner), pp. 41-88. Birkhauser Basel, Switzerland.

Bilen S. \& Bulut M. (2010) Effects of laurel (Laurus nobilis) on the non-specific immune responses of rainbow trout (Oncorhynchus mykiss, Walbaum). Journal of Animal and Veterinary Advances 9(8), 1275-1279.

Bondad-Reantaso M.G., Subasinghe R.P., Arthur J.R., Ogawa K., Chinabut S., Adlard R., Tan Z. \& Shariff M. (2005) Disease and health management in Asian aquaculture. Veterinary Parasitology 132, 249-272.

Cabello F.C. (2006) Heavy use of prophylactic antibiotics in aquaculture: a growing problem for human and animal health and for the environment. Environmental Microbiology 8, 1137-1144.

Chen X., Wu Z. \& Yin J. (2003) Effects of four species of herbs on immune function of Carassius auratus gibelio. Journal of Fishery Sciences of China 10, 36-40.

Cheng A.C., Chen Y.Y. \& Chen J.C. (2008) Dietary administration of sodium alginate and $\kappa$-carrageenan enhances the innate immune response of brown-marbled grouper Epinephelus fuscoguttatus and its resistance against Vibrio alginolyticus. Veterinary Immunology and Immunopathology 121(3-4), 206-215.

Choi S.W., Son B.W., Son Y.S., Park Y.I., Lee S.K. \& Chung M.H. (2001) The wound-healing effect of a glycoprotein fraction isolated from Aloe vera. The British Journal of Dermatology 145(4), 535-545.

Choi S.H., Park K.H., Yoon T.J., Kim J.B., Jang Y.S. \& 
Choe C.H. (2008) Dietary Korean mistele to enhances cellular non-specific immune responses and survival of Japanese eel (Anguilla japonica). Fish and Shellfish Immunology 24, 67-73.

Christybapita D., Divyagnaneswari M. \& Dinakaran M.R. (2007) Oral administration of Eclipta alba leaf aqueous extract enhances the non-specific immune responses and disease resistance of Oreochromis mossambicus. Fish and Shellfish Immunology 23(4), 840-852.

Citarasu T., Babu M.M., Sekar R.J.R. \& Marian P.M. (2002) Developing Artemia enriched Herbal diet for producing quality larvae in Penaeus monodon, Fabricius. Asian Fisheries Science 15, 21-32.

Citarasu T., Sivaram V., Immanuel G., Rout N. \& Murugan V. (2006) Influence of selected Indian immunostimulant herbs against white spot syndrome virus (WSSV) infection in black tiger shrimp, Penaeus monodon with reference to haematological, biochemical and immunological changes. Fish and Shellfish Immunology 21(4), 372-384.

Divyagnaneswari M., Christybapita D. \& Dinakaran M.R. (2007) Enhancement of non-specific immunity and disease resistance in Oreochromis mossambicus by Solanum trilobatum leaf fractions. Fish and Shellfish Immunology 23(2), 249-259.

Dugenci S.K., Arda N. \& Candan A. (2003) Some medicinal plants as immunostimulant for fish. Journal of Ethnopharmacology 88(1), 99-106.

Ellis A.E. (1990) Lysozyme assay. In: Techniques in Fish Immunology (ed. by J. S. Stolen, D. P. Fletcher, B. S. Anderson \& B. S. Robertson), pp. 101-103. SOS Publication, Fair Haven, New Jersey, USA.

Esteban M.A., Mulero V., Cuesta A., Ortuno J. \& Meseguer J. (2000) Effects of injecting chitin particles on the innate immune responses of gilthead seabream (Sparus aurata). Fish and Shelfish Immunology 10(6), 543-554.

Farag R.S., Dawz Z.Y., Hewedi F.M. \& El-Barotyl G.S.
(1989) Antimicrobial activity of some Egyptian Spice essential oils. Journal of Food Protection 52(9), 665-667.

Gabor E.F., Aurel S., Bențea M., Călina C. \& Anca B. (2012) The effect of phytoadditive combinations on growth and consumption indices and resistance to Aeromonas hydrophila in common carp (Cyprinus carpio) juveniles. Animal Science and Biotechnologies 45(2), 48-52.

Galina J., Yin G., Ardo L. \& Jeney Z. (2009) The use of immunostimulating herbs in fish. An overview of research. Fish Physiology and Biochemistry 35(4), 669-676.

Gopalakannan A. \& Arul V. (2006) Immunomodulatory effects of dietary intake of chitin, chitosan and levamisole on the immune system of Cyprinus carpio and control of Aeromonas hydrophila infection in ponds. Aquaculture 255, 179-187.

Haghighi M. \& Sharifrohani M. (2013) The effects of powdered ginger rhizome (Zingiber officinale) on haematological and immunological parameters of rainbow trout Oncorhynchus mykiss. Asian Journal of Marine Sciences 1, 7-11.

Harikrishnan R., Balasundaram C., Kim M.C., Kim J.S., Han Y.J. \& Heo M.S. (2009) Innate immune response and disease resistance in Carassius auratus by triherbal solvent extracts. Fish and Shellfish Immunology 27(3), 508-515.

Harikrishnan R., Balasundaram C. \& Heo M.S. (2010) Herbal supplementation diets on hematology and innate immunity in goldfish against Aeromonas hydrophila. Fish and Shellfish Immunology 28(2), 354-361.

Harikrishnan R., Balasundaram C. \& Heo M.S. (2011) Impact of plant products on innate and adaptive immune system of cultured finfish and shellfish. Aquaculture 317, 1-15.

Harikrishnan R., Kim D.H., Hong S.H., Mariappan P., Balasundaram C. \& Heo M.S. (2012) Non-specific immune response and disease resistance induced by Siegesbeckia glabrescens against Vibrio parahaemolyticus in Epinephelus bruneus. Fish and Shellfish Immunology 33(2), 359-364. 
Ispir U. \& Dörücü M. (2005) A Study on the Effects of Levamisole on the Immune System of Rainbow Trout (Oncorhynchus mykiss, Walbaum). Turkish Journal of Veterinary and Animal Sciences 29(5), 1169-1176.

Jeney G. \& Jeney Z. (2002) Application of immunostimulants for modulation of the non-specific defense mechanisms in sturgeon hybrid: Acipenser ruthenus, A. baerii. Journal of Applied Ichthyology 18, 416-419.

Jian J. \& Wu Z. (2003) Effects of traditional Chinese medicine on non-specific immunity and disease resistance of large yellow croaker, Pseudosciaena crocea (Richardson). Aquaculture 218, 1-9.

Jian J. \& Wu Z. (2004) Influence of traditional Chinese medicine on non-specific immunity of Jian Carp (Cyprinus carpio var. Jian). Fish and Shellfish Immunology 16(2), 185-191.

Kaattari S.L. \& Piganelli J.D. (1997) Immunization with bacterial antigens: Bacterial kidney disease. Developments in Biological Standardization 90, 145-152.

Kajita Y., Sakai M., Atsuta S. \& Kobayash M. (1990) The immunonodulatory effects of levamisole on rainbow trout, Oncorhynchus mykiss. Fish Pathology 25(2), 93-98.

Kim K.H., Hwang Y.J. \& Bai S.C. (1999) Resistance to Vibrio alginolyticus in juvenile rockfish (Sebastes schlegeli) fed diets containing different doses of aloe. Aquaculture $180,13-21$.

Kirubakan C.J.W., Alexander P.C. \& Dinakaran M.R. (2010) Enhancement of non-specific immune responses and disease resistance on oral administration of Nyctandthes arbortristis seed extract in Oreochromis mossambicus (Peters). Aquaculture Research 41, 1630-1639.

Lawless J. \& Allan J. (2000) Aloe vera-natural wonder cure. Harper Collins Publishers, London.

Lee J.K., Lee M.K., Yun Y.P., Kim Y., Kim J.S. \& Kim Y.S. (2001) Acemannan purified from Aloe vera induces phe- notypic and functional maturation of immature dendritic cells. International Immunopharmacology 1(7), 1275-1284.

Leong J.C. \& Fryer J.L. (1993) Viral vaccines for aquaculture. Annual Review of Fish Diseases 3, 225-240.

Liaghat M., Akhlaghi M., Hosseini A., Nematollahi A. \& Hosseini S.M. (2011) Humoral and non-specific immune responses in rainbow trout (O. mykiss) naturally exposed to and immunized with Streptococcus iniae. International Journal of Veterinary Research 5(4), 218-224.

Lowry O.H., Rosebrough N.J., Farr A.L. \& Randall R.J. (1951) Protein measurement with the folin phenol reagent. The Journal of Biological Chemistry 193, 265-275.

Misra C.K., Das B.K., Mukherjee S.C. \& Meher P.K. (2006) The immunomodulatory effects of tuftsin on the non-specific immune system of Indian Major carp, Labeo rohita. Fish and Shellfish Immunology 20(5), 728-738.

Murray A.L., Pascho R.J., Alcorn S.W., Fairgrieve W.T., Shearer K.D. \& Roley D.D. (2003) Effect of various feed supplements containing fish protein hydrolysate or fish processing by-products on the innate immune functions of juvenile coho salmon (Oncorhynchus kisutch). Aquaculture 220, 643-653.

Navinchandran M., Lyapparaj P., Moovendhan S., Ramasubburayan R., Prakash S., Immanuel G. \& Palavesam A. (2014) Influence of probiotic bacterium Bacillus cereus isolated from the gut of wild shrimp Penaeus monodon in turn as a potent growth promoter and immune enhancer in P. monodon. Fish and Shellfish Immunology 36, 38-45.

Naylor R.L., Goldburg R.J., Primavera J.H., Kautsky N., Beveridge M.C.M., Clay J., Folke C., Lubchenco J., Mooney H. \& Troell M. (2000) Effect of aquaculture on world fish supplies. Nature 405, 1017-1024.

Ortuño J., Esteban M.A. \& Meseguer J. (1999) Effect of high dietary intake of vitamin $\mathrm{C}$ on non-specific immune response of gilthead seabream (Sparus aurata L.). Fish and Shellfish Immunology 9(5), 429-443.

Ortuño J., Cuesta A., Esteban M.A. \& Meseguer J. (2001) Effect of oral administration of high vitamin $\mathrm{C}$ and $\mathrm{E}$ dos- 
ages on the gilthead seabream (Sparus aurata L.) innate immune system. Veterinary Immunology and Immunopathology 79(3-4), 167-180.

Press C.M. \& Lillehauge A. (1995) Vaccination in European salmonid aquaculture: A review of practices and prospects. The British Veterinary Journal 151, 45-69.

Pugh N., Ross S.A., El Sohly M.A. \& Pasco D.S. (2001) Characterization of Aloeridae, a new high molecular-weight polysaccharide from Aloe vera with potent immunostimulatory activity. Journal of Agricultural and Food Chemistry 49(2), 1030-1034.

Quesada S.P., Paschoal J.A.R. \& Reyes F.G.R. (2013) Considerations on the aquaculture development and on the use of veterinary drugs: special issue for fluoroquinolones- a review. Journal of Food Science 78, 1321-1333.

Raa J. (1996) The use of immunostimulatory substances in fish and shellfish farming. Review in Fisheries Science 4(3), 229-288.

Rao Y.V., Das B.K., Jyotymayee P. \& Chakraborli R. (2006) Effect of Achyranthes aspera on the immunity and survival of Labeo rohita infected with Aeromonas hydrophila. Fish and Shellfish Immunology 20(3), 263-273.

Rooijakkers S.H. \& van Strijp J.A. (2007) Bacterial complement evasion. Molecular Immunology 44(1-3), 23-32.

Sağdiç O. \& Özcan M. (2003) Antibacterial activity of Turkish spice hydrosols. Food Control 14(3), 141-143.

Sahu S., Das B.K., Pradhan J., Mohapatra B.K., Mishra B.K. \& Sarangi N.N. (2007) Effect of Magnifera indica kernal as a feed additive in immunity and resistance to Aeromonas hydrophila in Labeo rohita fingerlings. Fish and Shellfish Immunology 23, 109-118.

Sakai M. (1999) Current research status of fish immunostimulants. Aquaculture 172, 63-92.

Shao B.M., Xu w., Dai H., Tu P., Li z. \& Gao X.M. (2004) A study on the Immune receptors for polysaccharides from the roots of Astragalus membranaceus, a Chinese medicinal Herb. Biochemical and Biophysical Research communications 320(4), 1103-1111.

Sivaram V., Babu M.M., Immanuel G., Murugadass S., Citarasu T. \& Marian M.P. (2004) Growth and immune response of juvenile greasy groupers (Epinephelus tauvina) fed with herbal antibacterial active principle supplemented diets against Vibrio harveyi infections. Aquaculture 237, 9-20.

Siwicki A.K., Anderson D.P. \& Rumsey G.L. (1994) Dietary intake of immunostimulants by rainbow trout affects non-specific immunity and protection against furunculosis. Veterinary Immunology and Immunopathology 41, 125-139.

Tan B.K. \& Vanitha J. (2004) Immunomodulatory and antimicrobial effects of some traditional Chinese medicinal herbs: a review. Current Medicinal Chemistry 11, 1423 1430 .

Vaseeharan B. \& Thaya R. (2013) Medicinal plant derivatives as immunostimulants: an alternative to chemotherapeutics and antibiotics in aquaculture. Aquaculture International 22(3), 1079-1091.

Vasudeva Y.R., Romesh M., Singh A. \& Chakrabarti R. (2004) Potentiation of antibody production in Indian major carp Labeo rohita, rohu, by Achyranthes aspera as a herbal feed ingredient. Aquaculture 238, 67-73.

Vasudeva Y.R. \& Chakrabarti R. (2005) Stimulation of immunity in Indian major carp Catla catla with herbal feed ingredients. Fish and Shellfish Immunology 18(4), $327-334$

Vasudeva Y.R., Das B.K., Jyotyrmayee P. \& Chakrabarti R. (2006) Effect of Achyranthes aspera on the immunity and survival of Labeo rohita infected with Aeromonas hydrophila. Fish and Shellfish Immunology 20(3), 263-273.

Verlhac V., Obach A., Gabaudan J., Scheup W. \& Hole R. (1998) Immunomodulation by dietary vitamin C and glucan in rainbow trout (Oncorhynchus mykiss). Fish and 
Shelfish Immunology 8, 409-424.

Wang C., Xu Q.Y., Xu H., Zhu Q., Zheng Q.S. \& Sun D.J. (2011) Effects of aloe powder on the growth performance and plasma indices of sturgeon (Acipenser baeri Brandt). Journal of Shanghai Ocean University 20(4), 541-545.

Wu C.C., Liu C.H., Chang Y.P. \& Hsieh S.L. (2010) Effects of hot-water extract of Toona sinensis on immune response and resistance to Aeromonas hydrophila in Oreochromis mossambicus. Fish and Shellfish Immunology 29, 258-263.

Yin G., Ardo L., Thompson K.D., Adams A., Jeney Z. \& Jeney G. (2009) Chinese herbs (Astragalus radix and Ganoderma lucidum) enhance immune response of carp, Cyprinus carpio, and protection against Aeromonas hydrophila. Fish and Shellfish Immunology 26, 140-145.

Yuan C., Li D., Chen W., Sun F., Wu G., Gong Y., Tang J., Shen M. \& Han X. (2007) Administration of a herbal immunoregulation mixture enhances some immune parameters in carp (Cyprinus carpio). Fish Physiology Biochemistry 33, 93-101.

Zodape G.V. (2010) Effect of Aloe vera Juice on Toxicity Induced by Metal (Chromium) in Labeo rohita (Hamilton). Journal of Applied Sciences Research 6(11), 17881793. 


\title{
تأثير جيره حاوى آلوئه ورا و اكيناسه بر ايمنى غيراختصاصى ماهى شيربت
}

(Barbus grypus)

\author{
م مصباح، ت محمديان، م عليشاهى، ا جنكرَان نزاد \\ بخش علوم درمانكاهى، دانشكده داميزشكى، دانشكاه شهيد جمران، اهواز، ايران
}

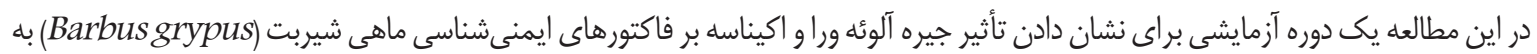

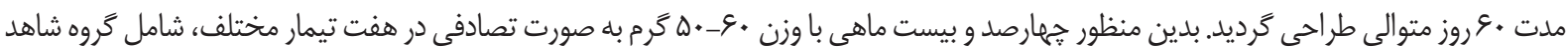

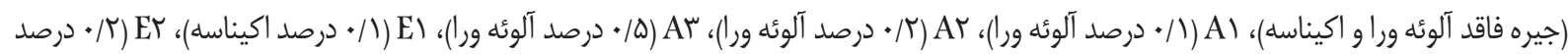

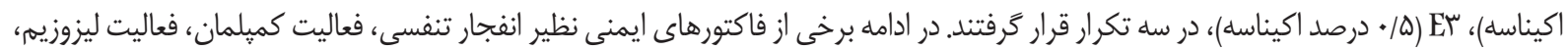

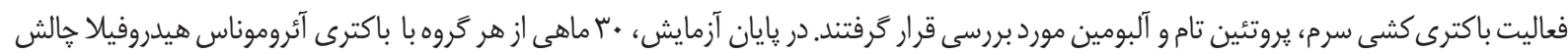

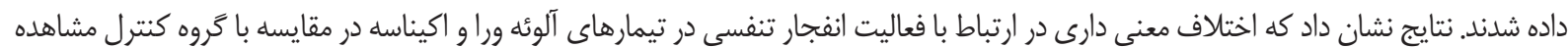

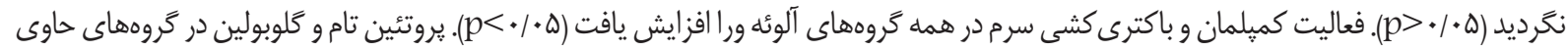

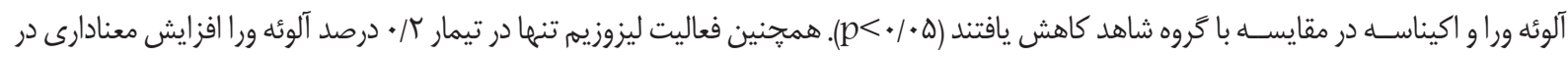

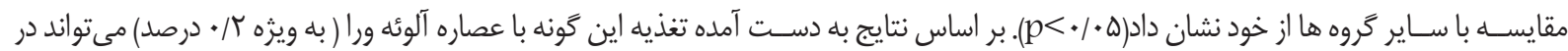
مقايسه با اكيناسه، موجب بهبود فاكتورهاى ايمنى شود. واثههاى كليدى : آلوئه ورا، Barbus grypus، اكيناسه، فاكتورهاى ايمنى. 